\title{
Cost-related Medication Nonadherence among Medicare Beneficiaries with Cardiovascular Disease Risk Factors: The Role of Comprehension of the Medicare Program and its Prescription Drug Benefits
}

\author{
Chanhyun Park ${ }^{1}$, Angela Chang ${ }^{1}$, Boon $\mathrm{Ng}^{2}$, and Gary Young ${ }^{1}$ \\ ${ }^{1}$ Northeastern University \\ ${ }^{2}$ University of Central Florida
}

November 24, 2021

\begin{abstract}
RATIONALE, AIMS, AND OBJECTIVES: This study aims to investigate how reported comprehension of the Medicare program and its prescription drug benefits affects cost-related medication nonadherence (CRN) among Medicare beneficiaries with cardiovascular disease (CVD) risk factors. METHODS: This cross-sectional study used the 2017 Medicare Current Beneficiary Survey Public Use File data and included Medicare beneficiaries aged [?] 65 years who reported having at least one CVD risk factor (i.e., hypertension, hyperlipidemia, diabetes, smoking, and obesity) ( $\mathrm{n}=2,821)$. A survey-weighted logistic model was used to examine associations between lack of difficulty understanding the Medicare program and its prescription drug benefits and CRN, controlling for beneficiaries' demographic (e.g., age) and clinical characteristics (e.g, comorbidities). This study further analyzed five subgroups based on the type of CVD risk factors involved. RESULTS: Among Medicare beneficiaries with CVD risk factors, $14.4 \%$ reported CRN. Medicare beneficiaries with CVD risk factors who reported difficulty understanding the overall Medicare program and its prescription drug benefits were more likely to report CRN, compared to those who reported easy understanding of the overall Medicare program $(\mathrm{OR}=1.49 ; 95 \% \mathrm{CI}=1.09,2.04 ; \mathrm{p}<0.001)$ and its prescription drug benefits $(\mathrm{OR}=2.01 ; 95 \% \mathrm{CI}=1.51,2.67 ; \mathrm{p}<0.001)$. Similar results were obtained for the subgroups with obesity, hypertension, or hyperlipidemia. CONCLUSIONS: Perceived lack of difficulty understanding the Medicare Program and its prescription drug benefits has a positive impact on CRN reduction among Medicare beneficiaries with CVD risk factors, especially those with obesity, hypertension or hyperlipidemia. Monitoring and enhancing Medicare beneficiaries' overall understanding of the Medicare program may reduce CRN.
\end{abstract}

\section{Hosted file}

CRN_Understanding_Main Text.docx available at https://authorea.com/users/447818/articles/ 546752-cost-related-medication-nonadherence-among-medicare-beneficiaries-withcardiovascular-disease-risk-factors-the-role-of-comprehension-of-the-medicare-programand-its-prescription-drug-benefits

\section{Hosted file}

CRN_Understanding_Tables.docx available at https://authorea.com/users/447818/articles/546752cost-related-medication-nonadherence-among-medicare-beneficiaries-with-cardiovasculardisease-risk-factors-the-role-of-comprehension-of-the-medicare-program-and-itsprescription-drug-benefits

\section{Hosted file}


CRN_Understanding_Figure.docx available at https://authorea.com/users/447818/articles/546752cost-related-medication-nonadherence-among-medicare-beneficiaries-with-cardiovasculardisease-risk-factors-the-role-of-comprehension-of-the-medicare-program-and-itsprescription-drug-benefits 